\title{
FACTORS AFFECTING THE VIABILITY AND GERMINATION BEHAVIOR OF CONIFEROUS SEED. VI. STRATIFICATION AND SUBSEQUENT TREATMENT, PSEUDOTSUGA MENZIESII (MIRB.) FRANCO'
}

\author{
By G. S. ALLEN ${ }^{2}$
}

ABSTRACT

Stratification effects increase with duration of treatment; short treatments accelerate germinaion markedly for incubation at $25^{\circ} \mathrm{C}$ but longer treatments are necessary for rapid germination at $15^{\circ}$ or $10^{\circ} \mathrm{C}$. Post stratification drying and storage reduce the stratification effect, particularly at low incubation temperatures, but do not adversely affect germinative capacity. Implications for seed testing and nursery practice are discussed.

INTRODUCTION

Stratification has long been used to hasten the germination of seed and has become common practice in tree nurseries of the Pacific Coast. It is an empirical technique based largely upon experience and varying in detail from nursery to nursery. Some use media to hold and supply moisture to the seed; others presoak the seed and then store it without medium at a temperature slightly above freezing.

Stratification not only accelerates germination at the commonly used incubation temperatures but it also makes germination possible at temperatures of $10^{\circ} \mathrm{C}$ or lower (Allen, 1960). Although growth at low temperature is confined largely, if not wholly, to the radicle, it does enable the root to penetrate the soil and become well established before any obvious top growth begins. This kind of behavior has been observed in March when the upper one-half inch of soil reached approximately: $15^{\circ} \mathrm{C}$ at mid-day. It may explain the superior development of fall-sown seedlings in comparison with late-spring sowings of either untreated or stratified seed. Early sowing of well stratified seed would probably simulate results from fall-sowing.

Stratification has disadvantages: the work involved in mixing seed and moist medium, the cost of cold storage for several weeks, and the difficulty of separating treated seed from medium or of handling moist seed. Most of these can be minimized by using the "naked stratification" technique described by Allen and Bientjes (1954) and by other means. Some seed users are concerned about possible effects of longer treatments, loss of moisture during treatment, and the waste that might occur should some of the treated seed not be used.

This report covers a miscellany of experiences with stratified seed of Douglas fir, taken from a number of studies made during the period 1959-61. Although the studies were not designed specifically for the purpose they do shed some light on the effects of stratification and subsequent storage on seed from a variety of origins. For this reason they have been brought together. Although generalizations are attempted, it is realized that most of the seed

\footnotetext{
1 Research Paper No. 53, Faculty of Forestry, University of British Columbia.

The support received for this and related work from the National Research Council of Canada is gratefully acknowledged. Mr. Louis Medveczky assisted in the laboratory tests.

- Formerly Dean, Faculty of Forestry, University of British Columbia; now Director of Forestry Research, Weyerhaeuser Company, Centralia, Wash., U.S.A.
} 
lots were of exceptionally high quality, having been processed by hand methods, and that the conclusions may not be valid for seed of lower quality.

\section{General}

\section{Methods and Results}

Stratification was accomplished by presoaking for 24 hours in tap water at room temperature, superficial drying, and storing in plastic vials inside looselidded sealers at $0-2^{\circ} \mathrm{C}$.

All test seeds were incubated on the surface of vermiculite at waterholding capacity in covered Petri dishes. Moisture content was checked frequently and brought to standard as necessary. Germinates were counted as soon as their radicles reached or passed 0.1 inch in length and then removed; abnormal germinates were recorded but not included in the data summaries given here. As usual for Douglas fir, abnormalities were mostly of the reversed embryo type in which the radicle is oriented away from instead of towards the micropyle. Two samples of 25 seeds each were used in all tests.

Test duration for stratified seed was usually 30 days although, with an incubation temperature of $15^{\circ} \mathrm{C}$. or $10^{\circ} \mathrm{C}$., this was often extended to 40 days. Unstratified seed was incubated for about 50 days when germination had usually ceased. Seeds still ungerminated at the end of the period were cut and classified as sound, deteriorated, insect-filled, or empty. Germination per cent (G) at the end of the test, and germinative capacity (GC, - germination per cent plus sound seed remaining) are shown for most tests along with a measure of the rate of germination, $\mathbf{R}$, the median value for germination time in days based upon germinative capacity.

Since several different studies are covered by this report, each will be described separately as an experiment, even though it was part of a larger study.

Experiment 1

Samples from 26 seed lots from a variety of locations in British Columbia, collected in 1959 , were stratified for $0+120$ days and tested at $25^{\circ} \mathrm{C} ., 15^{\circ} \mathrm{C}$., and $10^{\circ} \mathrm{C}$. All but six seed lots came from individual mother trees; those six lots were area collections included to show the range in behavior among areas for comparison with the range among trees. Six lots are of Interior origin (F15, F16, F17, F20, F21, and F23) and the remainder came from the Coast. Values of $\mathbf{G}, \mathbf{G C}$, and $\mathbf{R}$ are given in Tables 1,2, and 3 for the three test temperatures.

The main features of the results are these:

1. In view of the limited sampling, germinative capacity at $25^{\circ} \mathrm{C}$ was remarkably uniform among unstratified seed and seed stratified for 10, 20, or 40 days. Only one lot, F13, showed a serious drop with increase in stratification period. Extended stratification ( 80 or 120 days) resulted in a definite decrease in the case of lots F13 and F15, and a possible decrease for lots F7, F12, and F35.

2. The median germination time at $25^{\circ} \mathrm{C}$ decreased from a range of $5.7-24.0$ days for unstratified seed to one of 2.7-6.7 days for seed stratified for 10 days. A relatively quick and reliable test is possible following 10 days' stratification by the technique used; little is gained, from the standpoint of testing, by using a longer period of stratification. This conflicts on the 
TABLE 1

G, GC, and R for 26 Lots of Douglas Fir Seed Following

STRATIFICATION FOR 0-120 DAYS. EXPERIMENT 1 . InCUbation AT $25^{\circ} \mathrm{C}$.

\begin{tabular}{|c|c|c|c|c|c|c|c|c|c|c|c|c|c|c|c|c|c|c|c|}
\hline $\begin{array}{l}\text { Lot } \\
\text { No. }\end{array}$ & Source ${ }^{1}$ & $G$ & $\underset{G C}{\text { Unstr }}$ & at. $\mathrm{R}$ & G & Strat. & $10 \mathrm{~d}_{\mathrm{R}}$ & $\underset{G}{\text { Strat }}$ & ${ }_{\mathrm{G}}^{20} \mathrm{C}$ & $\mathbf{R}$ & $\underset{G}{\text { Strat. }}$ & ${ }^{4} \underset{\mathrm{GC}}{\mathrm{C}}$ & $R$ & $\underset{G}{\text { Stra }}$ & $\begin{array}{r}80 \\
\mathrm{GC}\end{array}$ & $\mathrm{d}_{\mathrm{R}}$ & $\underset{\mathbf{G}}{\text { Stra }}$ & t. 120 & $\frac{d}{R}$ \\
\hline $\mathrm{F} 1$ & $\mathrm{UBCF}$ & 90 & $\overline{901}$ & 6.6 & 86 & 86 & 4.3 & 100 & 100 & 4.6 & 90 & 90 & 3.9 & $\overline{94}$ & 94 & 3.5 & 82 & $\overline{82}$ & 2.9 \\
\hline $\mathrm{F} 2$ & UBCF & 96 & 96 & 15.0 & 92 & 92 & 3.9 & 96 & 96 & 3.8 & $98^{\prime}$ & 98 & 3.8 & 96 & 96 & 3.5 & 92 & 92 & 2.9 \\
\hline${ }^{*} \mathrm{~F} 4$ & $\mathrm{UBCF}$ & 82 & 82 & 8.7 & 58 & 62 & 5.7 & 78 & 78 & 5.6 & 72 & 72 & 5.5 & 70 & 70 & 5.0 & 70 & 70 & 6.2 \\
\hline${ }^{*} \mathrm{~F} 7$ & UBCF & 92 & 94 & 6.4 & 90 & 90 & 4.9 & 90 & 90 & 4.5 & 92 & 92 & 4.1 & 86 & 86 & 4.2 & 82 & 82 & 4.7 \\
\hline$* \mathrm{~F} 8$ & UBCF & 76 & 76 & 8.7 & 92 & 92 & 4.3 & 72 & 72 & 3.5 & 84 & 84 & 3.6 & 84 & 84 & 4.0 & 92 & 92 & 3.6 \\
\hline *F9 & UBCF & 72 & 76 & 18.3 & 68 & 68 & 5.2 & 68 & 68 & 4.4 & 76 & 80 & 5.0 & 68 & 76 & 6.6 & 72 & 72 & 5.0 \\
\hline${ }^{*} \mathrm{~F} 10$ & UBCF & 92 & 92 & 15.5 & 92 & 92 & 3.8 & 96 & 96 & 3.1 & 100 & 100 & 3.6 & 84 & 84 & 3.6 & 84 & 84 & 2.7 \\
\hline *F11 & Campbell $\mathrm{R}$. & 92 & 92 & 14.5 & 100 & 100 & 3.9 & 96 & 96 & 3.6 & 96 & 96 & 2.9 & 100 & 100 & 2.8 & 98 & 98 & 2.6 \\
\hline${ }^{*} \mathrm{~F} 12$ & Campbell $\mathbf{R}$ & 80 & 80 & 10.7 & 78 & 80 & 4.9 & 69 & 68 & 5.7 & 72 & 76 & 5.0 & 72 & 72 & 5.6 & 64 & 66 & 4.1 \\
\hline *F13 & Campbell $\mathbf{R}$. & 42 & 70 & 38.0 & 50 & 74 & 14.5 & 42 & 48 & 13.0 & 34 & 36 & 7.5 & 30 & 36 & 9.0 & 36 & 36 & 8.0 \\
\hline *F14 & Campbell $\mathrm{R}$. & 100 & 100 & 8.3 & 96 & 98 & 5.1 & 94 & 96 & 5.0 & 96 & 96 & 5.4 & 90 & 90 & 6.1 & 94 & 94 & 4.01 \\
\hline F15 & Solsqua & 88 & 90 & 18.7 & 92 & 94 & 4.0 & 92 & 92 & 3.0 & 96 & 96 & 3.1 & 60 & 60 & 2.6 & 14 & 14 & 1.0 \\
\hline F16 & Alta Lk. & 90 & 90 & 8.1 & 80 & 80 & 4.3 & 94 & 94 & 3.5 & 92 & 92 & 3.7 & 90 & 90 & 3.1 & 90 & 90 & 2.7 \\
\hline *F17 & Falkland & 98 & 98 & 9.9 & 98 & 98 & 2.7 & 98 & 98 & 1.7 & 98 & 98 & 1.6 & 98 & 98 & 1.5 & 98 & 98 & 0.8 \\
\hline${ }^{*} \mathrm{~F} 20$ & Falkland & 94 & 94 & 8.6 & 94 & 94 & 4.7 & 92 & 92 & 3.8 & 86 & 86 & 2.9 & 100 & 100 & 2.2 & 100 & 100 & 1.5 \\
\hline *F21 & Falkland & 96 & 98 & 13.2 & 98 & 98 & 3.8 & 100 & 100 & 2.8 & 100 & 100 & 2.7 & 100 & 100 & 2.6 & 92 & 92 & 2.2 \\
\hline${ }^{*} \mathrm{~F} 23$ & Falkland & 92 & 92 & 23.0 & 88 & 88 & 4.8 & 96 & 96 & 4.3 & 96 & 96 & 4.1 & 96 & 96 & 2.9 & 96 & 96 & 2.3 \\
\hline${ }^{*} \mathrm{~F} 25$ & $\mathrm{UBCC}$ & 86 & 86 & 5.9 & 90 & 90 & 2.8 & 90 & 90 & 2.9 & 82 & 82 & 2.8 & 96 & 96 & 2.7 & 92 & 92 & 2.4 \\
\hline *F27 & UBCC & 74 & 78 & 17.8 & 84 & 84 & 6.7 & 78 & $78 i$ & 4.0 & 86 & 86 & 3.7 & 84 & 84 & 4.3 & 80 & 80 & 2.9 \\
\hline${ }^{*} \mathrm{~F} 30$ & UBCC & 90 & 90 & 19.5 & 86 & 90 & 4.3 & 96 & 96 & 3.7 & 92 & 92 & 3.0 & 94 & 94 & 3.3 & 92 & 92 & 3.6 \\
\hline${ }^{*} \mathrm{~F} 32$ & UBCC & 96 & 96 & 9.0 & 100 & 100 & 2.8 & 98 & 98 & 2.9 & 100 & 100 & 3.2 & 96 & 96 & 2.6 & 100 & 100 & 2.5 \\
\hline *F33 & UBCC & 86 & 86 & 24.0 & 98 & 98 & 4.5 & 94 & 94 & 4.2 & 96 & 96 & 3.4 & 98 & 98 & 2.6 & 98 & 98 & 2.5 \\
\hline *F34 & UBCC & 80 & 80 & 22.7 & 96 & 96 & 4.3 & 86 & 86 & 4.4 & 98 & 98 & 4.2 & $98^{\prime}$ & 98 & 3.4 & 92 & 92 & 2.5 \\
\hline$* \mathrm{~F} 35$ & UBCC & 86 & 90 & 15.3 & 88 & 88 & 5.3 & 88 & 88 & 4.8 & 88 & 88 & 4.8 & 74 & 80 & 5.8 & 80 & 80 & 4.4 \\
\hline \multirow[t]{2}{*}{ F89 } & Mt. & & & & & & & & & & & & & & & & & & \\
\hline & Benson, V.I. & 88 & 89 & 5.7 & - & 一 & 一 & 98 & 98 & 4.4 & 94 & 94 & 3.8 & 94 & 94 & 3.4 & 100 & 100 & 2.3 \\
\hline F90 & Cedar, V.I. & 89 & 90 & 14.2 & - & 一 & 一 & 96 & 96 & 6.3 & 92 & 92 & 5.4 & 98 & 98 & 3.5 & 90 & 90 & 2.4 \\
\hline
\end{tabular}


TABLE 2

G, GC, ANd R For 26 Lots of Douglas Fir SeEd Following

Stratification FOR 0-120 DAYs. EXPERIMENT 1.INCUBation at $15^{\circ} \mathrm{C}$.

\begin{tabular}{|c|c|c|c|c|c|c|c|c|c|c|c|c|c|}
\hline \multirow{2}{*}{$\begin{array}{c}\begin{array}{c}\text { Lot } \\
\text { No. }\end{array} \\
\text { F1 }\end{array}$} & \multirow{2}{*}{$\frac{\text { Source }}{\mathrm{UBCF}}$} & \multicolumn{3}{|c|}{ G $\underset{\text { GC }}{\text { Strat. }} 20 \frac{d}{R}$} & \multicolumn{3}{|c|}{$\mathrm{G} \stackrel{\text { Strat. }}{40} \underset{\mathrm{R}}{\mathrm{d}}$} & \multicolumn{3}{|c|}{$\mathrm{G} \underset{\mathrm{GC}}{\text { Strat. } 80} \mathrm{~d}_{\mathrm{R}}$} & \multicolumn{3}{|c|}{$\mathrm{G}_{\mathrm{GC}}^{\text {Strat. }}{ }_{\mathrm{R}}^{120} \mathrm{~d}$} \\
\hline & & 16 & 54 & $30+$ & 56 & 72 & 15.7 & 84 & 84 & 7.7 & 72 & 72 & 7.3 \\
\hline F2 & UBCF & 16 & 58 & $30+$ & 76 & 86 & 11.8 & 82 & 86 & 8.8 & $98 i$ & $10 a$ & 7.4 \\
\hline F4 & UBCF & 2 & 42 & $30+$ & 8 & 64 & $30+$ & 26 & 66 & $30+$ & 62 & 74 & 12.3 \\
\hline F7 & UBCF & 10 & 46 & $30+$ & 26 & 86 & $30+$ & 60 & 84 & 11.6 & 58 & 86 & 11.7 \\
\hline F8 & UBCF & 48 & 68 & 9.7 & 80 & 80 & 8.0 & 72 & 76 & 8.9 & 68 & 68 & 8.6 \\
\hline F9 & UBCF & 12 & 80 & $30+$ & 12 & 88 & $30+$ & 44 & 80 & 18.0 & 72 & 76 & 10.2 \\
\hline F10 & UBCF & 32 & 92 & $30+$ & 88 & 96 & 8.6 & 96 & 96 & 8.5 & 100 & 100 & 6.6 \\
\hline F11 & Campbell R. & 22 & 80 & $30+$ & 80 & 90 & 9.1 & 96 & 100 & 7.6 & 96 & 96 & 6.7 \\
\hline F12 & Campbell R. & 8 & 82 & $30+$ & 42 & 74 & 12.7 & 40 & 68 & 14.9 & 60 & 72 & 10.4 \\
\hline F13 & Campbell R. & 4 & 66 & $30+$ & 2 & 68 & $30+$ & 4 & 48 & $30+$ & 8 & 38 & $30+$ \\
\hline F14 & Campbell R. & 0 & 94 & $301+$ & 10 & 94 & $30+$ & 6 & 86 & $30+$ & 70 & 96 & 12.0 \\
\hline F15 & Solsqua & 60 & 82 & 8.0 & 96 & 98 & 6.0 & 18 & 70 & $30+$ & 8 & 78 & $30+$ \\
\hline F16 & Alta Lk. & 32 & 58 & 13.8 & 74 & 84 & 11.2 & 94 & 94 & 8.5 & 88 & 88 & 6.4 \\
\hline F17 & Falkland & 86 & 96 & 5.6 & 96 & 96 & 4.6 & 98 & 98 & 4.4 & 96 & 96 & 3.1 \\
\hline F20 & Falkland & 86 & 88 & 6.5 & 98 & 98 & 5.6 & 100 & 100 & 4.9 & 100 & 100 & 3.5 \\
\hline F21 & Falkland & 98 & 98 & 6.7 & 100 & 100 & 7.1 & 94 & 94 & 5.7 & 98 & 98 & 5.5 \\
\hline F23 & Falkland & 100 & 100 & 7.5 & 96 & 96 & 6.0 & 88 & 92 & 5.7 & 84 & 84 & 5.3 \\
\hline F25 & UBCC & 22 & 60 & $30+$ & 88 & 818 & 10.2 & 84 & 84 & 7.2 & 90 & 90 & 5.7 \\
\hline F27 & UBCC & 0 & 74 & $30+$ & 38 & 82 & $30+$ & 70 & 84 & 8.6 & 90 & 90 & 6.2 \\
\hline F30 & UBCC & 20 & 74 & $30+$ & 82 & 92 & 7.7 & 100 & 100 & 7.7 & 88 & 88 & 8.5 \\
\hline F32 & UBCC & 4 & 48 & $30+$ & 22 & 48 & $30+$ & 100 & 100 & 8.2 & 100 & 100 & 6.4 \\
\hline F33 & $\mathrm{UBCC}$ & $a$ & 40 & $30+$ & 42 & 60 & 14.5 & 98 & 98 & 6.3 & 96 & 96 & 6.6 \\
\hline F34 & UBCC & 2 & 48 & $30+$ & 46 & 66 & 15.5 & 92 & 92 & 7.9 & 92 & 92 & 5.9 \\
\hline F35 & $\mathrm{UBCC}$ & 18 & 96 & $30+$ & 38 & 90 & $30+$ & 64 & 88 & 12.9 & 76 & 84 & 9.5 \\
\hline F89 & Mt. Benson, V.I. & - & - & - & 78 & 92 & 12.2 & 92 & 92 & 8.8 & 94 & 96 & 6.1 \\
\hline F90 & Cedar, V.I. & - & 一 & 一 & 38 & 88 & $30+$ & 82 & 86 & 9.6 & 90 & 94 & 7.4 \\
\hline
\end{tabular}

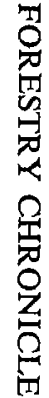

${ }^{1}$ UBCF-University Research Forest, Haney, B.C.

UBCC-University of B.C. campus area, Point Grey, B.C. 
TABLE 3

G, GC, AND R FOR 26 LOTS OF DOUGLAS FIR SEEd FOLlowing STRATIFICATION FOR 0-120 DaYs. EXPERIMENT 1 . InCubation AT $15^{\circ} \mathrm{C}$.

\begin{tabular}{|c|c|c|c|c|c|c|c|c|c|c|}
\hline $\begin{array}{l}\text { Lot } \\
\text { No. }\end{array}$ & Source & $\mathrm{G}^{\mathrm{S}}$ & trat. & $0 d_{\mathbf{R}}$ & G & Strat. 8 & $0 \mathbf{d}_{\mathbf{R}}$ & G & trat. & $0 \frac{\mathrm{d}}{\mathbf{R}}$ \\
\hline $\mathrm{F} 1$ & UBCF & 12 & 74 & $30+$ & 94 & 94 & 18. & 66 & 66 & 11.9 \\
\hline $\mathrm{F} 2$ & UBCF & 6 & 74 & $30+$ & 16 & 90 & 17.8 & 4 & 100 & 12.4 \\
\hline${ }^{*} \mathrm{~F} 4$ & UBCF & 2 & 74 & $30+$ & 8 & 72 & $30+$ & 24 & 62 & $30+$ \\
\hline${ }^{*} \mathrm{~F} 7$ & UBCF & 4 & 78 & $30+$ & 14 & 88 & $30+$ & $38^{\circ}$ & 76 & 27.0 \\
\hline${ }^{*} \mathrm{~F} 8$ & UBCF & 44 & 76 & 23.5 & 72 & 76 & 15.6 & 52 & 60 & 14.5 \\
\hline${ }^{*} \mathrm{~F} 9$ & UBCF & 4 & 92 & $30+$ & 8 & 68 & $30+$ & 48 & 68 & 18.2 \\
\hline${ }^{*} \mathrm{~F} 10$ & UBCF & 4 & 96 & $30+$ & 60 & 92 & 15 & 88 & 92 & 11.1 \\
\hline *F11 & Campbell $\mathbf{R}$. & 12 & 96 & $30+$ & 98 & 98 & 12.8 & 100 & 100 & 10.6 \\
\hline${ }^{*} \mathrm{~F} 12$ & Campbell R. & 0 & 90 & $30+$ & 14 & 80 & $30+$ & 32 & 70 & $30+$ \\
\hline${ }^{*} \mathrm{~F} 13$ & Campbell R. & $a$ & 68 & $30+$ & 4 & 52 & $30+$ & 14 & 46 & $301+$ \\
\hline${ }^{*} \mathrm{~F} 14$ & Campbell $\mathbf{R}$. & 0 & 92 & 30 & 2 & 88 & 30 & 44 & 96 & $30+$ \\
\hline F15 & Solsqua & 74 & 78 & 12.6 & 22 & 84 & $30+$ & 4 & 88 & $301+$ \\
\hline F16 & Alta Lk. & 20 & 64 & $30+$ & 94 & 94 & 14.3 & 74 & 74 & 9.4 \\
\hline$* F 17$ & Falkland & 92 & 94 & 8.3 & 98 & 98 & 7 & 92 & 92 & 4.8 \\
\hline${ }^{*} \mathrm{~F} 20$ & Falk & 98 & 98 & 9. & 90 & 92 & 8. & 100 & 100 & 5.6 \\
\hline${ }^{*} \mathrm{~F} 21$ & Falkland & 94 & 94 & 10.9 & 96 & 96 & 10 & 98 & 98 & 8.7 \\
\hline$* F 23$ & Falkland & 72 & 78 & 10.8 & 92 & 92 & 10 & 100 & 100 & 9.4 \\
\hline${ }^{*} \mathrm{~F} 25$ & $\mathrm{UIBCC}$ & 22 & 76 & $30+$ & 94 & 94 & 12.8 & 96 & 96 & 9.4 \\
\hline${ }^{*} \mathrm{~F} 27$ & UBCC & 0 & 72 & $30+$ & 54 & 78 & 14 & 82 & 86 & 9.4 \\
\hline *F30 & UBCC & 8 & 76 & $30+$ & 74 & 92 & 13.2 & 76 & 86 & 15.5 \\
\hline${ }^{*} \mathrm{~F} 32$ & UBCC & 0 & 50 & $30+$ & 96 & 96 & 15 & 96 & 96 & 9.8 \\
\hline${ }^{*} \mathrm{~F} 33$ & UBCC & 2 & 88 & $30+$ & 100 & 100 & 12 & 100 & 100 & 10.6 \\
\hline${ }^{*} \mathrm{~F} 34$ & UBCC & 4 & 70 & $30+$ & 96 & 96 & 13.9 & 96 & 96 & 9.2 \\
\hline${ }^{*}$ F35 & UBCC & 6 & 84 & $30+$ & 2 & 94 & $30+$ & 60 & 78 & 15.2 \\
\hline F89 & Mt. Ben & 一 & - & - & 92 & 94 & 13.2 & $98:$ & 100 & 10.3 \\
\hline F90 & Cedar, V.I. & - & - & 一 & 90 & 100 & 17.2 & 88 & 96 & 10.3 \\
\hline
\end{tabular}

${ }^{1}$ UBCF-University Research Forest, Haney, B.C.

UBCC-University of B.C. campus area, Point Grey, B.C.

* Single-tree collection.

surface with previous recommendations based upon attaining maximum rate of germination following treatment (Allen, 1941; Allen and Bientjes, 1954).

3. Extended stratification for 80 days or longer was of value when incubation temperatures were low. Relatively rapid germination occurred at $15^{\circ} \mathrm{C}$ following 80-120 days' stratification. Since this is of the order of surface-soil temperature during the natural outdoor germination period for Douglas fir, long stratification which simulates overwintering outdoors may have value in nursery practice when fall sowing is impossible or inconvenient. Extended treatment and early spring sowing should encourage early root establishment prior to top development.

4. Most seed lots showed their full germinative capacity at all three incubation 
temperatures provided that the seed was adequately stratified ( 80 days or longer) in the case of the two lower temperatures. To this extent, the germinative capacity indicated by the tests was the same regardless of the duration of stratification and the incubation temperature.

\section{Experiment 2}

Seed from seven lots, after 120 days' stratification, was treated in one of three ways.

(a) dried at room temperature for 7 days in open dishes, soaked 16 hours at room temperature, and incubated at $25^{\circ} \mathrm{C}$.

(b) dried as in (a), then stored in capped vials at room temperature for an additional 7 days, soaked, incubated at $25^{\circ} \mathrm{C}$.

(c) dried as in (a), then stored in capped vials for an additional 525 days at room temperature, soaked, incubated at $25^{\circ} \mathrm{C}$.

The results are given in Table 4 together with the pertinent data from

Table 1 for comparison. The highlights are as follows:

TABLE 4

G, GC, and R for Six Lots of Douglas Fir Seed Stratified 0-120 Days Followed by Drying and Storage. Experiment 2. Incubation at $25^{\circ} \mathrm{C}$.

\begin{tabular}{|c|c|c|c|c|c|c|c|c|c|c|}
\hline & & G & GC & $\mathbf{R}$ & G & GC & $\mathrm{R}$ & G & GC & $\mathbf{R}$ \\
\hline & & \multicolumn{3}{|c|}{ Lot $F 1$} & \multicolumn{3}{|c|}{ Lot F2 } & \multicolumn{3}{|c|}{ Lot F11 } \\
\hline \multirow{10}{*}{$\begin{array}{l}12 \\
12 \\
12\end{array}$} & 0 & 90 & 90 & 6.6 & 96 & 96 & 15.0 & 92 & 92 & 14.5 \\
\hline & 10 & 86 & 86 & 4.3 & 92 & 92 & 3.9 & 100 & 100 & 3.9 \\
\hline & 20 & 100 & 100 & 4.6 & 96 & 96 & 3.8 & 96 & 96 & 3.6 \\
\hline & 40 & 90 & 90 & 3.9 & 98 & 98 & 3.8 & 96 & 96 & 2.9 \\
\hline & 80 & 94 & 94 & 3.5 & 96 & 96 & 3.5 & 100 & 100 & 2.8 \\
\hline & 120 & 82 & 82 & 2.9 & 92 & 92 & 2.9 & 98 & 98 & 2.6 \\
\hline & $-a^{1}$ & 72 & 72 & 2.6 & 92 & 92 & 2.8 & 100 & 100 & 2.3 \\
\hline & $-b^{2}$ & 60 & 60 & 2.5 & 100 & 100 & 3.0 & 96 & 96 & 2.6 \\
\hline & $-c^{3}$ & 68 & 68 & 5.1 & - & - & 一 & 92 & 92 & 7.9 \\
\hline & & \multicolumn{3}{|c|}{ Lot F25 } & \multicolumn{3}{|c|}{ Lot F32 } & \multicolumn{3}{|c|}{ Lot $F_{33}$} \\
\hline \multirow[t]{9}{*}{ Strat. } & 0 & 86 & 86 & 5.9 & 96 & 96 & 9.0 & 86 & 86 & 24.0 \\
\hline & 10 & 90 & 90 & 2.8 & 100 & 100 & 2.8 & 98 & $98 i$ & 4.5 \\
\hline & 20 & 90 & 90 & 2.9 & 98 & 98 & 2.9 & 94 & 94 & 4.2 \\
\hline & 40 & 82 & 82 & 2.8 & 100 & 100 & 3.2 & 96 & 96 & 3.4 \\
\hline & 80 & 96 & 96 & 2.7 & 96 & 96 & 2.6 & 98 & 98 & 2.6 \\
\hline & 120 & 92 & 92 & 2.4 & 100 & 100 & 2.5 & 98 & 98 & 2.5 \\
\hline & $0-a$ & 92 & 92 & 2.3 & 100 & 100 & 1.7 & 100 & 100 & 2.4 \\
\hline & $0-b$ & 80 & 80 & 2.0 & 100 & 100 & 1.7 & 100 & 100 & 2.4 \\
\hline & $D-c$ & 60 & 60 & 7.2 & 88 & 88 & 5.1 & 92 & 92 & 6.9 \\
\hline
\end{tabular}

${ }^{2} 120-a=$ residue from 120 days strat., dried R.T. 7 days open vials; soaked 16 hrs. R.T., incub. $25^{\circ} \mathrm{C}$.

120-b $=$ as " $"$ " but stored 1 week after drying, in capped vials at R.T.

" $120-c=$ as " $b$ " but stored in capped vials 525 days R.T. 
Treatment (a) produced no loss in germinative capacity, and either no change or a slight increase in rate of germination. Drying at room temperature for 7 days to approximately 10 per cent moisture content, following stratification, had no measurable harmful effects.

Treatment (b) generally resulted in no unfavorable effects.

Treatment (c), with the seed dried to about 10 per cent moisture content and held there for about 18 months, generally had little effect upon germinative capacity but did decrease the rate of germination markedly. Nevertheless, only in one case definitely (F25) of six tested, did the rate slow down to that of the original unstratified seed. To this extent, under the conditions of the experiment, stratification effects were only partially nullified by low moisture content brought about by extended storage.

\section{Experiment 3}

Seed of a very slow lot, F34, was stratified for 64 days at a moisture content of about $80 \%$. Samples were tested at $10^{\circ}, 15^{\circ}$, and $25^{\circ} \mathrm{C}$ after the following treatments;

A. no further treatment.

B. dried at room temperature 4 days to moisture content of about 10 per cent.

(a) stored in capped vials at room temperature for 16 days.

(b) no further storage.

(c) stored open at room temperature for 16 days.

C. As in $\mathrm{B}$ but dried at $0-2^{\circ} \mathrm{C}$ to about 40 per cent moisture content:

(a) stored in capped vials at $0-2^{\circ} \mathrm{C}$ for 16 days.

(b) no further storage.

(c) stored open at $0-2^{\circ} \mathrm{C}$ for 16 days.

D. Residue from 64 days' stratification stored open at $0-2^{\circ} \mathrm{C}$ for 274 days.

E. Unstratified control.

The results are given in Table 5 with highlights as follows:

TABLE 5

G, GC, and R for Seed Lot F34 Stratified 64 Days Followed by Various Storage Treatments. Experiment 3. Incubation at $25^{\circ}, 15^{\circ}$, and $10^{\circ} \mathrm{C}$.

\begin{tabular}{|c|c|c|c|c|c|c|c|c|c|}
\hline \multirow{3}{*}{ Treatment } & \multicolumn{9}{|c|}{ Incubation Temperature } \\
\hline & \multicolumn{3}{|c|}{$25^{\circ} \mathrm{C}$} & \multicolumn{3}{|c|}{$15^{\circ} \mathrm{C}$} & \multicolumn{3}{|c|}{$10^{\circ} \mathrm{C}$} \\
\hline & $\overline{\mathrm{G}}$ & $\mathrm{GC}$ & $\bar{R}$ & $\overline{\mathrm{G}}$ & $\mathrm{GC}$ & $\overline{\mathrm{R}}$ & $\overline{\mathbf{G}}$ & GC & $\overline{\mathbf{R}}$ \\
\hline A. & 92 & 92 & 3.3 & 100 & 100 & 7.5 & 100 & 100 & 13.1 \\
\hline B. (a) & 94 & 96 & 5.7 & 28 & 96 & $50+$ & 0 & 100 & $50+$ \\
\hline (b) & 100 & 100 & 4.2 & 88 & 100 & 9.6 & 40 & 92 & $50+$ \\
\hline (c) & 84 & 88 & 5.7 & 7 & 92 & $50+$ & 0 & 92 & $50+$ \\
\hline C. (a) & 94 & 94 & 2.8 & 96 & 96 & 6.2 & 92 & 92 & 9.2 \\
\hline (b) & 96 & 96 & 3.8 & 96 & 100 & 8.5 & 96 & 100 & 14.2 \\
\hline (c) & 94 & 94 & 3.8 & 98 & 98 & 9.4 & 100 & 100 & 14.7 \\
\hline D. & 96 & 96 & 7.0 & - & - & - & - & - & - \\
\hline E. & 72 & 90 & 21.7 & - & - & - & - & - & - \\
\hline
\end{tabular}


Germinative capacity held up under all treatments with the possible exception of $B(c)$. Rate of germination was increased by $C(a)$ but in all other treatments the rate was lower than for A, incubated after 64 days' stratification. At $25^{\circ} \mathrm{C}$, no treatment nullified the stratification effect completely. Drying at room temperature slowed germination more than did drying for the same period of time at $0-2^{\circ} \mathrm{C}$. But further storage at $0-2^{\circ} \mathrm{C}$ at 40 per cent moisture content, for a total stratification of 80 days, had a further stratification effect, nearly equivalent in total of that provided by 120 days' stratification (see Tables 1,2 and $3,-\mathrm{F} 34$ ).

In general, no ill effects resulted from drying the seed after 64 days' stratification but the effects of stratification were partially nullified by drying to 10 per cent moisture and holding for 16 days. Drying to 40 per cent and further storage at $0-2^{\circ} \mathrm{C}$, however, were beneficial; this is consistent with the view expressed previously (Allen, 1962) that 40 per cent moisture content permits effective stratification.

Experiment 4 follows:

Seed lot F34 (see Tables 1-3), a relatively "dormant" lot, was treated as

A. Stratified 34 days.

B. As A, but dried open at room temperature for 7 days to approximately 10 per cent moisture content.

C. As B, but room storage continued for a total of 14 days.

D. Unstratified. results:

The seeds were tested at $15^{\circ} \mathrm{C}$ and $25^{\circ} \mathrm{C}$ for 40 days, with the following

TABLE 6

G, GC, and R for SeEd Lot F34 Unstratified and Stratified for 34 Days Followed by Drying and Storage. EXPERIMENT 4. InCubation at $25^{\circ}$ AND $15^{\circ} \mathrm{C}$.

\begin{tabular}{|c|c|c|c|c|c|c|c|}
\hline & \multirow{3}{*}{ Treatment } & \multicolumn{6}{|c|}{ Incubation Temperature } \\
\hline & & \multicolumn{3}{|c|}{$15^{\circ} \mathrm{C}$} & \multicolumn{3}{|c|}{$25^{\circ} \mathrm{C}$} \\
\hline & & $\bar{G}$ & GC & $\bar{R}$ & G & $\mathrm{GC}$ & $\mathrm{R}$ \\
\hline A. & Stratified & 78 & 98 & 11.3 & 98 & 98 & 3.8 \\
\hline B. & Stratified, stored 7 days & 6 & 100 & $40+$ & 96 & 98 & 4.0 \\
\hline C. & Stratified, stored 14 days & - & — & - & 82 & 96 & 6.5 \\
\hline D. & Unstratified & - & - & - & 56 & 94 & 24.0 \\
\hline
\end{tabular}

These data indicate that the 7-day drying had little effect on behavior at $25^{\circ} \mathrm{C}$ but a marked effect on that at $15^{\circ} \mathrm{C}$. Extension of room-temperature storage to 14 days, on the other hand, slowed germination at $25^{\circ} \mathrm{C}$ but had no effect upon germinative capacity. C still retained a considerable stratification effect compared with $\mathrm{D}$, but less than that shown after 10 days' stratification (see Table 1, F34).

Experiment 5

Collections were made from two adjacent trees, 10/34 and 11/34 in September, 1959, when cones were browning (lots F27 and F34, respectively, 
Table 1) and again in January, 1960, when about two-thirds of the seed had been disseminated.

The four lots were tested shortly after collection at $25^{\circ} \mathrm{C}$ unstratified, and at $15^{\circ} \mathrm{C}$ and $25^{\circ} \mathrm{C}$ after 20 days' stratification, and again in SeptemberNovember, 1960 , at $25^{\circ} \mathrm{C}$ unstratified. The unused residue from the January, 1960 , collection was left in stratification for a total of 288 days and then tested at $25^{\circ} \mathrm{C}$.

TABLE 7

G, GC, and R for Seed From Two Trees, Collected in September, 1959, AND JANUARY, 1960. EXPERIMENT 5.

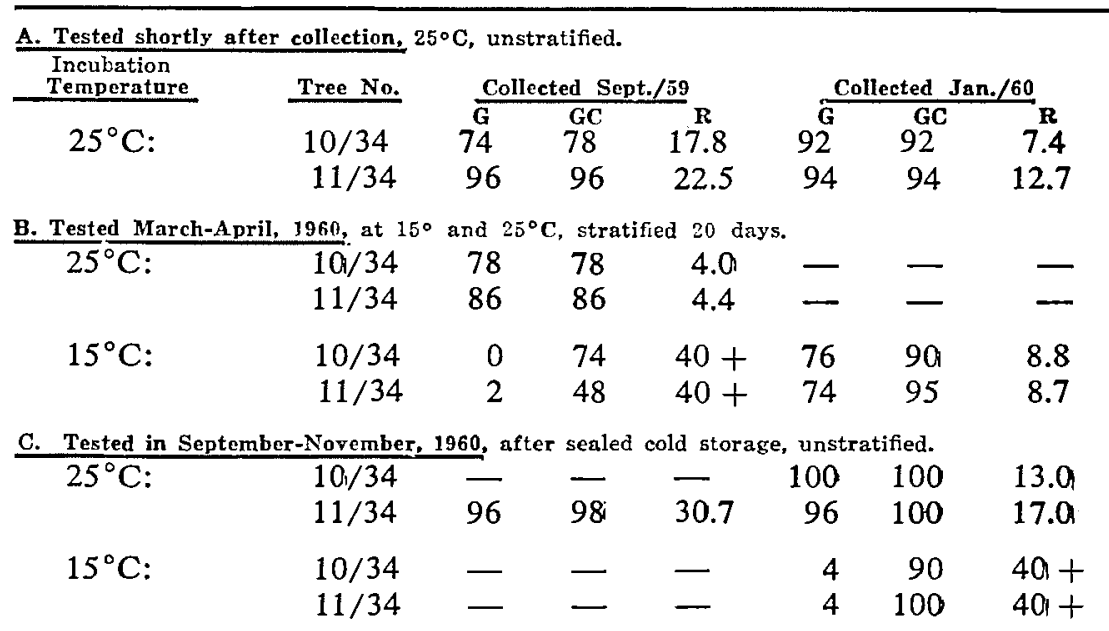

D. Tested at $25^{\circ} \mathrm{C}$ after 288 days' stratification, January, 1960 , collection only :

10/34. All germinated at $0-2^{\circ} \mathrm{C} ; \mathrm{G}=85.7 \%$.

$11 / 34$. $30 \%$ germinated at $0+2{ }^{\circ} \mathrm{C} ; \mathrm{G}$ of remainder $=96 \% ; \mathrm{R}=0.67$.

The data under $\mathbf{A}$ indicate that the equivalent of stratification took place on the tree within the cones between September and January and resulted in faster germination. The data under B show a marked effect of "storage" on the tree on germination rate at $15^{\circ} \mathrm{C}$ following 20 days' stratification; the late collection behaved as if it had had between 40 and 80 days' stratification (see Table 2, F27 and F34) rather than 20. The results under C show that approximately six months' dry cold storage slowed germination of both the early and the late collections. The data under $\mathrm{D}$ are of interest only because of the germination obtained at $0-2^{\circ} \mathrm{C}$ and the maintenance of full germinative capacity during 9 months' stratification.

Experiment 6

Two U.B.C. Forest collections, U21 and U22, were stratified in the normal way (A), and open in the refrigerator at $0-2^{\circ} \mathrm{C}(\mathrm{B})$ for 43 days and 266 days. Moisture contents of $\mathrm{U} 21$ and $\mathrm{U} 22$ at the beginning of stratification were $80 \%$ and $86 \%$, respectively. At the end of 43 days no change had taken 
place in $A$ whereas, in $B$, moisture content had dropped to 24-25. By the end of 288 days of stratification, $A$ had dropped to $6-7 \%$ and $B$ to $11-13 \%$ moisture content. Tests were conducted at $15^{\circ} \mathrm{C}$ and $25^{\circ} \mathrm{C}$ with the following results:

TABLE 8

G, GC, and $R$ for Two SEed Lots Stratified in Two Ways for 43 and 266 Days. Experiment 6. InCUBation at $25^{\circ} \mathrm{C}$ AND $15^{\circ} \mathrm{C}$.

\begin{tabular}{|c|c|c|c|c|c|c|c|c|c|c|c|c|c|}
\hline \multirow[b]{2}{*}{$\begin{array}{c}\text { Treatment } \\
\text { Period } \\
\end{array}$} & \multirow[b]{2}{*}{$\begin{array}{l}\text { Incub. } \\
\text { Temp. }\end{array}$} & \multicolumn{6}{|c|}{ Treatment A } & \multicolumn{5}{|c|}{ Treatment B } & \multirow[b]{2}{*}{ 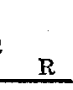 } \\
\hline & & $\mathrm{G}$ & $\begin{array}{l}\mathrm{U}^{-} \\
\mathrm{GC} \\
\end{array}$ & $\mathbf{R}$ & $G$ & $\begin{array}{c}\mathrm{U} 22 \\
\text { GC }\end{array}$ & $\underline{\mathbf{R}}$ & $\mathrm{G}$ & $\begin{array}{r}\text { U21 } \\
\text { GC }\end{array}$ & $\underline{\mathbf{R}}$ & $\mathrm{G}$ & $\begin{array}{r}\text { U22 } \\
\text { GC }\end{array}$ & \\
\hline 43 days & $\begin{array}{l}25^{\circ} \mathrm{C} \\
15^{\circ} \mathrm{C}\end{array}$ & $\begin{array}{l}92 \\
94\end{array}$ & $\begin{array}{l}92 \\
94\end{array}$ & $\begin{array}{l}3.4 \\
7.5\end{array}$ & $\begin{array}{l}88 \\
98\end{array}$ & $\begin{array}{l}88 \\
98\end{array}$ & $\begin{array}{l}2.8 \\
6.3\end{array}$ & $\begin{array}{l}84 \\
90\end{array}$ & $\begin{array}{l}84 \\
92\end{array}$ & $\begin{array}{l}3.8 \\
9.8\end{array}$ & $\begin{array}{l}90 \\
92\end{array}$ & $\begin{array}{l}90 \\
96\end{array}$ & $\begin{array}{l}4.3 \\
9.9\end{array}$ \\
\hline 266 day & $\begin{array}{l}25^{\circ} \mathrm{C} \\
15^{\circ} \mathrm{C}\end{array}$ & $\begin{array}{l}78 \\
72\end{array}$ & $\begin{array}{l}78 \\
76\end{array}$ & $\begin{array}{r}8.3 \\
21.7\end{array}$ & $\begin{array}{l}86 \\
88\end{array}$ & $\begin{array}{l}90 \\
90\end{array}$ & $\begin{array}{r}7.3 \\
17.5\end{array}$ & $\begin{array}{l}92 \\
76\end{array}$ & $\begin{array}{l}92 \\
90\end{array}$ & $\begin{array}{r}7.5 \\
20.3\end{array}$ & $\begin{array}{l}92 \\
90\end{array}$ & $\begin{array}{l}92 \\
90\end{array}$ & $\begin{array}{r}7.6 \\
18.2\end{array}$ \\
\hline
\end{tabular}

With stratification for 43 days, treatment $B$ was somewhat less effective than $\mathrm{A}$, particularly when incubation was at $15^{\circ} \mathrm{C}$. During extended stratification with steady drying of seed, the effectiveness of treatment gradually lessened; some loss of germinative capacity was indicated for U21 under treatment A. Experiment 7

Seeds from reciprocal crosses were collected in September, 1958, and tested at $25^{\circ} \mathrm{C}$ the following summer after 51 days' stratification. The residue was left in capped vials for a total storage of 275 days at $0-2^{\circ} \mathrm{C}$ during which the moisture content dropped from about $60 \%$ to an estimated $20 \%$. These seeds were tested at $25^{\circ} \mathrm{C}$. The following show the results of the original tests made in 1959 and the final made in 1960.

TABLE 9

G, GC, and R for Douglas Fir Seed From Reciprocal Crosses Untreated AND STRATIFIEd FOR 51 OR 275 Days. EXPERIMENT 7. INCUBATION at $25^{\circ} \mathrm{C}$.

\begin{tabular}{|c|c|c|c|c|c|c|c|c|c|}
\hline \multirow{2}{*}{ Cross } & \multicolumn{6}{|c|}{1959 Test } & \multicolumn{3}{|c|}{$\begin{array}{l}1960 \text { Test } \\
\text { Strat. } 275 \text { davs }\end{array}$} \\
\hline & $\bar{G}$ & GC & $\underline{R}$ & $\mathrm{G}$ & GC & $R$ & $\mathrm{G}$ & $\mathrm{GC}$ & $\mathbf{R}$ \\
\hline $\mathrm{E}_{+} \times \mathrm{A}$ & 87 & 97 & 17.4 & 94 & 94 & 4.8 & 90 & 90 & 5.6 \\
\hline$E_{o} \times B$ & 90 & 90 & 10.0 & - & - & - & 100 & 100 & 5.6 \\
\hline $\mathrm{B}_{\mathrm{o}}^{+} \times \mathrm{E}$ & 87 & 97 & 13.9 & 88 & 88 & 3.7 & 100 & 100 & 4.2 \\
\hline $\begin{array}{r}\mathbf{B}_{o} \times \mathrm{A} \\
+ \\
\end{array}$ & 27 & 85 & $30+$ & 87 & 87 & 3.4 & 100 & 100 & 3.5 \\
\hline
\end{tabular}

The most striking aspect of these data is the ability of carefully processed seed to endure, without loss, up to 9 months' stratification. The untreated seed varied widely in "dormancy" at $25^{\circ} \mathrm{C}$ but much less after either 51 days' or 275 days' stratification.

Experiment 8

The residue of Interior seed lots $F 17, F 18, F 20, F 21$ and F22 from the study reported in part as Experiment 1, after 120 days' stratification, was treated 
as follows:

A. no further treatment.

B. dried 7 days open at room temperature to moisture content of about $10 \%$.

C. as $B$ but at room temperature 14 days.

D. dried and stored open in refrigerator at $0-2^{\circ} \mathrm{C}$ for 14 days.

TABLE 10

G, GC, and $\mathbf{R}$ for Five Interior Seed Lots Stratified for 120 Days Followed by DRying and Storage. Experiment 8. INCUBATION AT $25^{\circ}, 15^{\circ}$, AND $10^{\circ} \mathrm{C}$.

\begin{tabular}{|c|c|c|c|c|c|c|c|c|c|c|}
\hline \multirow{3}{*}{$\begin{array}{l}\text { Lot } \\
\text { No. }\end{array}$} & \multirow{3}{*}{ Treatment } & \multicolumn{9}{|c|}{ Incubation Temperature } \\
\hline & & \multicolumn{3}{|c|}{$25^{\circ} \mathrm{C}$} & \multicolumn{3}{|c|}{$15^{\circ} \mathrm{C}$} & \multicolumn{3}{|c|}{$10^{\circ} \mathrm{C}$} \\
\hline & & $\bar{G}$ & GC & $\overline{\mathbf{R}}$ & $\bar{G}$ & GC & $\overline{\mathbf{R}}$ & $\mathbf{G}$ & GC & $\overline{\mathbf{R}}$ \\
\hline \multirow[t]{4}{*}{ F17 } & A & 98 & 98 & 0.8 & 96 & 96 & 3.1 & 92 & 92 & 4.8 \\
\hline & $\mathrm{B}$ & 96 & 96 & 1.6 & 100 & 100 & 2.4 & 96 & 96 & 3.7 \\
\hline & $\mathrm{C}$ & 100 & 100 & 1.2 & 96 & 96 & 3.1 & 92 & 96 & 3.9 \\
\hline & $\mathrm{D}$ & 92 & 92 & 1.3 & 96 & 96 & 2.7 & 100 & 100 & 3.5 \\
\hline \multirow[t]{4}{*}{ F18 } & A & 92 & 92 & 3.0 & 80 & 88 & 7.1 & 82 & 818 & 11.6 \\
\hline & B & 72 & 72 & 2.7 & 80 & 80 & 6.2 & 76 & 76 & 7.6 \\
\hline & $\mathrm{C}$ & 72 & 80 & 3.3 & 56 & 92 & 7.5 & 24 & 80 & $21+$ \\
\hline & $\mathrm{D}$ & 80 & 80 & 2.8 & 88 & 88 & 6.2 & 43 & 74 & 12.7 \\
\hline \multirow[t]{4}{*}{ F20 } & $A$ & 100 & 100 & 1.5 & 100 & 100 & 3.5 & 100 & 100 & 5.6 \\
\hline & B & 92 & 92 & 2.0 & 92 & 92 & 2.8 & 100 & 100 & 4.9 \\
\hline & C & 90 & 90 & 2.1 & 76 & 84 & 3.7 & 92 & 100 & 6.1 \\
\hline & D & 78 & 78 & 1.8 & 92 & 92 & 3.0 & 92 & 96 & 4.7 \\
\hline \multirow[t]{4}{*}{$\mathrm{F} 21$} & A & 92 & 92 & 2.2 & 98 & 98 & 5.5 & 98 & 98 & 8.7 \\
\hline & B & 96 & 96 & 2.8 & 96 & 96 & 5.2 & 100 & 100 & 6.6 \\
\hline & C & - & - & - & - & - & - & - & - & - \\
\hline & $\mathrm{D}$ & 100 & 100 & 2.6 & 100 & 100 & 4.9 & 100 & $10 ; 0$ & 7.0 \\
\hline \multirow[t]{4}{*}{$\mathrm{F} 22$} & A & 94 & 94 & 2.8 & 94 & 94 & 6.4 & 88 & 88 & 10.2 \\
\hline & B & 80 & 80 & 3.0 & 88 & 88 & 4.2 & 88 & 88 & 6.0 \\
\hline & $\mathrm{C}$ & 86 & 90 & 3.2 & 76 & 94 & 6.1 & 68 & 88 & 10.5 \\
\hline & $\mathbb{D}$ & 90 & 90 & 4.2 & 80 & 90 & 6.0 & 80 & 92 & 7.8 \\
\hline
\end{tabular}

Using $A$ for each seed lot as the basis for comparison, it is apparent that treatment $\mathrm{B}$ has generally resulted in faster germination at $15^{\circ} \mathrm{C}$ and $10^{\circ} \mathrm{C}$ but not at $25^{\circ} \mathrm{C}$. This behavior may be accounted for by the effect of higher temperature during drying at room temperature $\left(25-25^{\circ} \mathrm{C}\right)$ while the seed was still moist enough to react. On the other hand, the effect of treatment $D$ was to extend stratification by 14 days and increase the rate of germination of some lots at the lower temperatures. In very few cases did any significant drop in germinative capacity result from treatments $\mathrm{B}$ or $\mathrm{D}$ compared with $\mathrm{A}$.

Treatment $\mathrm{C}$, however, resulted either in slower germination than $\mathrm{A}$ or in about the same rate, suggesting that any advantage of higher temperature during initial drying was offset by the extended period at low moisture content during which the stratification effect was gradually lost. 


\section{CONCLUSTONS}

Stratification nearly always accelerates germination without affecting germinative capacity. Its effect is increased with duration of treatment, particularly at low incubation temperatures. At $25^{\circ} \mathrm{C}$ the first few days of stratification have the greatest relative effect upon rate of germination.

Stratification effects are slowly reversible as moisture content is dropped below about $40 \%$. Even prolonged storage following stratification and drying to about $10 \%$ rarely offset the stratification effect completely and have little if any effect upon germinative capacity in the case of high quality seed. Reversal of stratification effects is more pronounced at low incubation temperatures than at high; "secondary dormancy" at low temperatures results quickly from drying but germinative capacity is retained.

The results suggest that good quality seed can be dried after stratification, if not needed, and stored at $0-2^{\circ} \mathrm{C}$ for at least one year with little loss. It can be stratified for 120 days or longer without loss of viability in most cases and then either used, continued in cold storage with gradual drying, or dried down to 10 per cent quickly and re-stored at $0+2^{\circ} \mathrm{C}$. Even limited roomtemperature storage at 10 per cent moisture is satisfactory for period of a few months.

One advantage of extended stratification is its hastening effect on germination at low temperatures, enabling protrusion of the radicle and root establishment early in the growing season. Short stratification, or long stratification followed by drying and further storage, do not provide this advantage. On the other hand, for seed testing a short period of stratification is adequate since incubation temperatures are near optimal.

\section{Literature Cited}

1. AlLEN, G. S. 1941. A standard germination test for Douglas fir seed. For. Chron. $17: 75-78$.

2. 1960. Factors affecting the viability and germination behavior of coniferous seed. IV. Stratification period and incubation temperature, Psezdotsuga menziesii (Mirb.) Franco. For. Chron. 36: 18-29.

3.

1962 Factors affecting the viability and germination behavior of coniferous seed. V. Seed moisture content during stratification and secondary storage, Pseudotsuga menziesii (Mirb.) Franco. For Chron. 38: 303-312.

4. and W. BIENTJES. 1954. Studies on coniferous tree seed at the University of British Columbia. For Chron. 30: 183-196. 